\title{
The Efficiency of Using Multi-Forms Motor Tasks Style in Learning Javelin Throwing Skills for the Students of the Faculty of Physical Education at Zagazig University "Dr. Nashwa Ahmed El-Sayed Kamel
}

\section{Abstract:}

This research aims at identifying the efficiency of using multi-forms motor tasks style (feedback form - video recorder - computer) in learning javelin throwing skills for the second-year undergraduate students at the Faculty of Physical Education for Girls, Zagazig University. The researcher has conducted an empirical study on a sample of second-year undergraduate students at the Faculty of Physical Education for Girls, Zagazig University. They were divided into four groups of (14) students each. The research tools included: physical tests - intelligence test - evaluation of the technical and quantitative performance in javelin throwing - the proposed educational program based on multi-forms motor tasks style.

\section{Key results:}

1- The efficiency of multiforms motor tasks style

(feedback form - video recorder - computer) in learning and mastering javelin throwing skills for the secondyear undergraduate students at the Faculty of Physical Education for Girls, Zagazig University.

2- The efficiency of using command teaching style (verbal explanations - practical model - correcting technical mistakes) in learning and mastering javelin throwing skills for the second-year undergraduate students at the Faculty of Physical Education for Girls, Zagazig University.

Key recommendations:

1- Using computer-based motor tasks style given its effective impact on the learning and mastery of javelin throwing skills for the secondyear undergraduate students at the Faculty of Physical Education for Girls, Zagazig University.

Introduction

and

Professor at the Department of Track and Field Events Faculty of Physical Education for Girls - Zagazig University 
Learning can be highly affected by the teaching methods and styles that the teacher adopts. Therefore, experimental and applied learning methods can be more easily and rapidly transmitted than indoctrination. New teaching methods have emerged in order to help in transmitting the focus, in the learning process, from the teacher, and the educational materials to the learner; which would help him in acquiring the basic learning skills. Modern studies and educational psychology theories proved that it's important that the learner teaches himself and exerts efforts in an attempt to modify his behavior in accordance with his own abilities and potentials.

The motor tasks style consists in taking into consideration the individual differences between the learners, given that they are not equal in terms of their physical abilities and skills; some are poor, some are moderate and others are excellent. Therefore, the teacher, in this method, shall put a lesson plan that takes into account the learners' different levels by providing multi-levels educational steps in a way that allows the learner to choose the level that corresponds to his own abilities and to continue to progress till he attains his final objective.

Joce Harrison (1966) has indicated that the main difference between motor tasks style (multi-levels selfapplication style) and other methods consists in the fact that the student chooses the level of difficulty in accordance with his own level and his ability to implement such motor task. When the teacher chooses this method, his objective will be to allow each student to acquire an experience about his entrylevel, his success in implementing such task and to pass to other motor tasks in order to learn and master the required skill.

Educational means are among the basic components by which the educational technology has been used as a means to address the learner's senses while learning. Educational means are mainly based on a better involvement of more than one sense in the formation of the learner's visualizations, perceptions and concepts than in the adopted 
style which depends on verbal explanations and the implementation of the model by the physical education teacher.

Javelin throw is a difficult event that depends on the player's physical abilities and characteristics, and can be affected by many mechanical and physical variables such as (speed, strength, etc.). This event is also characterized by its rapidity and by the fact that its movements become simultaneous and complementary during the approach stage (the last five steps), especially the last step (the final throwing stage). All this stages require from the trainer to be accurate while choosing the trainings related to the type of performance. Furthermore, the main objective of throwing events is to keep the tool away from the throwing path or to push it as far as possible without prejudice to the rules of the event.

Given the researcher's scientific and practical experience as a member of the teaching staff at the department of track and field events at the Faculty of Physical Education for Girls, Zagazig University, she has noticed a remarkable deficiency in the technical and quantitative performance level of javelin throwing skills among the second-year undergraduate students at the Faculty of Physical Education compared to the required level, and this in spite of the availability of the necessary tools (field - tools) for the learning of the skills under consideration.

The researcher indicates that in spite of the variety and diversity of teaching styles at the Faculty of Physical Education, the teaching of the curriculum of track and field events for the second-year undergraduate students at the faculty is still based and depends on command teaching style. Furthermore, the high increase in the number of the second-year undergraduate students at the faculty makes it difficult for the teacher to conduct the process of teaching, supervising, directing, counseling and follow-up while correcting the technical mistakes of this huge number of students during the practical lessons, which exhausts the teacher seen that her major preoccupation, while teaching the educational 
module, becomes to maintain order without taking into consideration the educational and pedagogical incomes in addition to neglecting the individual differences between the students. Most of the time, the teacher commits the mistake of not giving an adequate opportunity for practice and self-learning.

To the researcher's knowledge and based on her regular readings in many relevant studies, she haven't found - to the researcher's best knowledge - one single study that handles the multi-form motor tasks style as a modern teaching style where the individual differences between students are taken into consideration through teaching javelin throwing skill in the form of progressive motor tasks of an easy-to-difficult order, so that the student could choose the task that corresponds to her abilities and potentialities, in addition to the use of some technical means in order to support motor tasks style in promoting the learning process, keeping pace with the modern age's technology, saving time and effort and promoting the level of technical and quantitative performance in javelin throwing skill among the second-year undergraduate students at the Faculty of Physical Education, Zagazig University.

\section{Objectives:}

The research aims at identifying the efficiency of using multi-forms motor tasks style (feedback form - video recorder - computer) in learning javelin throwing skill for the second-year undergraduate students at the Faculty of Physical Education for Girls, Zagazig University, through the following secondary objectives:

1- Identifying the efficiency of using multi-forms motor tasks style (feedback form - video recorder computer) on the level of technical and quantitative performance in javelin throwing skills.

2- Identifying the efficiency of using command teaching style (verbal explanations - practical method) on the level of technical and quantitative performance in javelin throwing skills.

3- Comparing the efficiency of using multi-forms motor tasks style (feedback 
form - video recorder computer) and command teaching style on the level of technical and quantitative performance in javelin throwing skill.

\section{Research hypotheses:}

1- There are statistically significant differences between the averages of post and pre tests of the first three experimental groups: the first experimental group (feedback form), the second experimental group (video recorder) and the third experimental group (computer) in terms of the level of technical and quantitative performance in javelin throwing skill in favor of the post test.

2- There are statistically significant differences between the averages of post and pre tests of the first experimental group (feedback form), the second experimental (video recorder) and the third experimental groups (computer) on the level of technical and quantitative performance in javelin throw skill in favor of the post test.

3- There are statistically significant differences between the averages of the post and pre tests of the first three experimental groups (feedback form - video recorder computer) and the control group (command teaching style) in terms of technical and quantitative performance in javelin throwing skill in favor of the third experimental group (computer).

\section{Research procedures:}

Methodology:

The researcher has adopted the empirical methodology seen that it suits the nature of the research's procedures through an experimental design of four groups, three of which are experimental and one is a control group, by means of the pre and post tests.

\section{Population and sample:}

By means of the purposive sampling, the researcher has chosen a sample of (68) among the (361) second-year undergraduate students of the Faculty of Physical Education for Girls, Zagazig University for the academic year 2014/2015, in the rate of $(18.84 \%)$.

(12) Students were excluded for the exploratory study, so the basic research sample would be (56) students divided into two groups: an experimental group and a control group of (12) students 
each. They were distributed as

shown in table (1)

Table (1)

Distribution of the basic research sample

\begin{tabular}{c|c|c|l}
\hline \hline Variable & Group & Number & \multicolumn{1}{|c}{ Teaching style } \\
\hline \hline 1 & $\begin{array}{c}\text { First experimental } \\
\text { group }\end{array}$ & 14 & $\begin{array}{l}\text { feedback form-based } \\
\text { motor tasks style }\end{array}$ \\
\hline 2 & $\begin{array}{c}\text { Second } \\
\text { experimental group }\end{array}$ & 14 & $\begin{array}{l}\text { Video recorder-based } \\
\text { motor tasks style }\end{array}$ \\
\hline 3 & $\begin{array}{c}\text { Third experimental } \\
\text { group }\end{array}$ & 14 & $\begin{array}{l}\text { Computer-based } \\
\text { motor tasks style }\end{array}$ \\
\hline 4 & Control group & 14 & Command teaching style \\
\hline \multicolumn{2}{|c|}{ Total } & \multicolumn{2}{c}{56} \\
\hline
\end{tabular}

The researcher has assured equivalence between the individuals of the research sample in terms of their growth rates (age - height - weight intelligence), physical variables under consideration and the level of technical and quantitative performance in javelin throw.

Equivalence among the research's four groups:

Equivalence has been established between the research's four groups (the three experimental groups - the control group) in terms of the previous variables under consideration, as shown in table (2):

\begin{tabular}{c|c|c|c|c|c}
\hline \hline Variables & $\begin{array}{c}\text { Source of } \\
\text { variance }\end{array}$ & $\begin{array}{c}\text { Total } \\
\text { sum of } \\
\text { squares }\end{array}$ & $\begin{array}{c}\text { Degree } \\
\text { of } \\
\text { freedom }\end{array}$ & $\begin{array}{c}\text { Mean } \\
\text { square }\end{array}$ & F value \\
\hline \hline Age & $\begin{array}{c}\text { Between } \\
\text { groups }\end{array}$ & 3.97 & 3 & 1.32 & 0.74 \\
\cline { 2 - 5 } & $\begin{array}{c}\text { Among } \\
\text { groups }\end{array}$ & 92.43 & 52 & 1.78 & \\
\hline Height & $\begin{array}{c}\text { Between } \\
\text { groups }\end{array}$ & 12.72 & 3 & 4.24 & 0.75 \\
\hline \hline
\end{tabular}

\begin{tabular}{c|c|c|c|c|c}
\hline \hline Variables & $\begin{array}{c}\text { Source of } \\
\text { variance }\end{array}$ & $\begin{array}{c}\text { Total } \\
\text { sum of } \\
\text { squares }\end{array}$ & $\begin{array}{c}\text { Degree of } \\
\text { freedom }\end{array}$ & $\begin{array}{c}\text { Mean } \\
\text { square }\end{array}$ & F value \\
\hline
\end{tabular}

Assiut Journal For Sport Science Arts 


\begin{tabular}{|c|c|c|c|c|c|}
\hline & $\begin{array}{l}\text { Among } \\
\text { groups }\end{array}$ & 390.12 & $\overline{52}$ & 7.50 & \\
\hline \multirow[t]{2}{*}{ Weight } & $\begin{array}{l}\text { Between } \\
\text { groups }\end{array}$ & 11.86 & 3 & 3.95 & \multirow[t]{2}{*}{0.62} \\
\hline & $\begin{array}{l}\text { Among } \\
\text { groups }\end{array}$ & 390.12 & 52 & 6.33 & \\
\hline \multirow[t]{2}{*}{ Intelligence } & $\begin{array}{l}\text { Between } \\
\text { groups }\end{array}$ & 7.92 & 3 & 2.64 & \multirow[t]{2}{*}{0.71} \\
\hline & $\begin{array}{l}\text { Among } \\
\text { groups }\end{array}$ & 193.61 & 52 & 3.72 & \\
\hline \multirow[t]{2}{*}{$\begin{array}{l}30 \mathrm{~m} \text { run with a } \\
\text { standing start }\end{array}$} & $\begin{array}{l}\text { Between } \\
\text { groups }\end{array}$ & 4.99 & 3 & 1.66 & \multirow[t]{2}{*}{0.81} \\
\hline & $\begin{array}{l}\text { Among } \\
\text { groups }\end{array}$ & 107.35 & 52 & 2.06 & \\
\hline \multirow[t]{2}{*}{$\begin{array}{l}\text { Standing } \\
\text { jump }\end{array}$} & $\begin{array}{l}\text { Between } \\
\text { groups }\end{array}$ & 3.86 & 3 & 1.29 & \multirow[t]{2}{*}{0.83} \\
\hline & $\begin{array}{l}\text { Among } \\
\text { groups }\end{array}$ & 81.29 & 52 & 1.56 & \\
\hline \multirow[t]{2}{*}{$\begin{array}{l}\text { Grip strength of } \\
\text { the throwing hand }\end{array}$} & $\begin{array}{l}\text { Between } \\
\text { groups }\end{array}$ & 12.81 & 3 & 4.27 & \multirow[t]{2}{*}{0.75} \\
\hline & $\begin{array}{l}\text { Among } \\
\text { groups }\end{array}$ & 297.94 & 52 & 5.73 & \\
\hline \multirow{2}{*}{$\begin{array}{l}\text { Throwing a } 800 \\
\text { gm ball to the } \\
\text { maximum distance }\end{array}$} & $\begin{array}{c}\text { Between } \\
\text { groups }\end{array}$ & 3.59 & 3 & 1.19 & \multirow[t]{2}{*}{0.61} \\
\hline & $\begin{array}{l}\text { Among } \\
\text { groups }\end{array}$ & 101.26 & 52 & 1.95 & \\
\hline \multirow[t]{2}{*}{ Standing bow } & $\begin{array}{l}\text { Between } \\
\text { groups }\end{array}$ & 4.83 & 3 & 1.61 & \multirow[t]{2}{*}{0.93} \\
\hline & $\begin{array}{l}\text { Among } \\
\text { groups }\end{array}$ & 90.17 & 52 & 1.73 & \\
\hline \multirow{2}{*}{$\begin{array}{l}\text { Level of technical } \\
\text { performance in } \\
\text { javelin throwing }\end{array}$} & $\begin{array}{c}\text { Between } \\
\text { groups }\end{array}$ & 0.94 & 3 & 0.31 & \multirow[t]{2}{*}{0.42} \\
\hline & $\begin{array}{l}\text { Among } \\
\text { groups }\end{array}$ & 38.11 & 52 & 0.73 & \\
\hline \multirow{2}{*}{$\begin{array}{l}\text { Level of } \\
\text { quantitative } \\
\text { performance in } \\
\text { javelin throwing }\end{array}$} & $\begin{array}{c}\text { Between } \\
\text { groups }\end{array}$ & 7.92 & 3 & 0.35 & \multirow[t]{2}{*}{0.64} \\
\hline & $\begin{array}{l}\text { Among } \\
\text { groups }\end{array}$ & 193.61 & 52 & 0.83 & \\
\hline
\end{tabular}

F value is at $0.05=2.79$ significance level

As table (2) shows, experimental groups and the there're no statistically control group in terms of significant differences at level growth rate, physical variables 0.05 between the three under consideration and the Assiut Journal For Sport Science Arts 
level of technical and quantitative performance in javelin throw, which means that the four research groups are equal.

Data collection tools:

First: physical tests under consideration:

1. $\quad 30 \mathrm{~m}$ run with a standing start test

1- $\quad$ Standing long jump test

2- Grip strength of the throwing hand test

3- $\quad$ Throwing a 800 gm ball to the maximum distance test

4- Standing bow test

Second: Evaluation of the level of performance of javelin throwing skill:

An assessment form has been designed by the researcher in order to evaluate the level of performance of javelin throwing skill. The form's coefficients (validity reliability) have been verified before application by submitting it to a group of specialists in track and field events. The results have shown the examiners' (100\%) agreement, which proves the validity of this form. Also, the reliability coefficient of the form has been calculated by applying the form and then reapplying it (7) days after the first application. The form's consistency coefficient has reached (0.892); the skill was rated out of (10) points distributed as follows:

- Grip (grasping the javelin) (one point)

- $\quad$ Holding the javelin (one point)

- Steady position

- $\quad$ Approach

(one point)

(two points)

- $\quad$ Throwing steps

- $\quad$ Releasing

(two points)

(two points)

- $\quad$ Balance "recovery"

(one point)

The level of performance of javelin throwing was evaluated by (3) experienced examiners in teaching track and field events, each one of them gave a mark to the student, and afterwards we calculated the average of all three marks.

Third: Measuring the quantitative level in javelin throwing

The researcher has measured the quantitative level in javelin throwing among the individuals of the basic research simple in accordance with the rules of IAAF - 
International Association of Athletics Federations.

\section{Fourth: intelligence test}

This test was prepared by Mohamed Khairy (1989) in order to measure general mental ability (intelligence). It can be applied on both sexes and all ages.

Educational program based on the multi-forms motor tasks style:

First: objective of the educational program:

1- Learning and mastering javelin throwing skill using multi-forms motor tasks style for the second-year undergraduate students at the Faculty of Physical Education for Girls, Zagazig University

Second: Basis for putting the educational plan:

The suggested educational plan was put in accordance with the following scientific basis:

1- The program content shall be compatible with the level and capacities of the individuals of the sample.

2- $\quad$ The educational steps shall progress from easy steps to composed steps.

3- Providing repetition and suitable groups for learning the skills under consideration.
4- Providing instructions and guidelines to show the right technical aspects of each educational step in order to avoid and correct mistakes.

5- Displaying illustrations of each educational step in the educational plan using the feedback form in order to give a "feedback" to the learner about the correct performance. 6- Using animations more than static or sequential images in order to show the educational steps of javelin throwing by video recorder.

7- Displaying a written text beside each illustration in order to make the student acquire the cognitive and applied aspects of javelin throwing using computer.

8- $\quad$ Providing the necessary facilities and tools for the program.

9- Taking into consideration security and safety factor during the implementation of the module of the suggested educational program.

\section{Third: Educational program content:}

The researcher has conducted a literary review of the educational steps of javelin throwing skills using many specialized scientific references in javelin throw 
events, and by adopting mainstream opinions of the experts of track and field events and teaching methods, and this in order to come out with the suitable educational steps. Thanks to the exploratory study led by the researcher, she was able to come out with the suitable educational steps for the research sample in order to learn javelin throwing skills, regulate the program, and make a schedule for the educational plan in which this content was prepared in the form of a feedback form for the first experimental group. The same content was also prepared in a way that is compatible with the video recorder for the second experimental group and in the form of educational software for the third experimental group. In the design of the educational program, the researcher was in business to make it have an easy-t-difficult order through the following:

- Breaking down the javelin throwing skill into little main stages in accordance with the stages of the implementation of the skill, and putting a series of simple educational steps for each stage in order to perform the skill as a whole.
- $\quad$ Conducting a set of skill trainings of an easy-to-difficult order, whether such trainings were done with or without tools.

- Taking into consideration the regulative aspects of the skill within the program.

\section{Schedule of the educational program:}

The researcher has identified (12) educational modules for the four groups of the research; two modules per week for (6) continuous weeks, the duration of each module is (90) minutes.

\section{Pre tests:}

Before conducting the pre tests, the researcher had taught two educational modules for the individuals of the basic research sample, so that all the individuals of the sample could reach a specific level starting from which the researcher would be able to conduct the pre tests for the individuals of the three experimental groups and the control group in terms of growth rates, physical variables and the level of technical and quantitative performance in javelin throw, for the period from 12/10/2014 till 14/10/2014.

Implementation of the suggested program: educational

\section{Assiut Journal For Sport Science Arts}


The content of the suggested educational program was applied on the individuals of the three experimental groups in the period from 16/10/2014 till 26/11/2014 for (6) weeks; two modules per week. The duration of each educational module was (90) minutes, the control group followed the command teaching style.

\section{Post tests:}

The researcher has conducted the post test for the three experimental groups and the control group in terms of the level of technical and quantitative performance of javelin throwing skills, for the period from 27/11/2014 till $30 / 11 / 2014$ following the same order and conditions of pre tests.

Presentation and discussion of results:

First: presentation and discussion of the results of the firs hypothesis which stipulate that: "there are statistically significant differences between the averages of the pre and post tests of the three experimental groups, the first experimental group (feedback form), the second experimental group (video recorder) and the third experimental group (computer) in terms of the level of technical and quantitative performance in the javelin throwing skill in favor of the post test."

Table (3)

Indication of the differences between the pre and post tests of the first experimental group in terms of the technical and quantitative performance $\mathrm{N}=14$

\begin{tabular}{|c|c|c|c|c|c|c|c|}
\hline \multirow{2}{*}{$\begin{array}{l}\text { Rate of } \\
\text { improvement }\end{array}$} & \multirow{2}{*}{$\begin{array}{l}\mathrm{T} \\
\text { value }\end{array}$} & \multicolumn{2}{|l|}{ Post test } & \multicolumn{2}{|l|}{ Pre test } & \multirow{2}{*}{$\begin{array}{lr}\text { Unit } & \text { of } \\
\text { Measurement }\end{array}$} & \multirow[t]{2}{*}{ Variables } \\
\hline & & dependent & Independent & dependent & Independent & & \\
\hline$\overline{597.65 \%}$ & $19.16^{*}$ & 0.74 & $\overline{5.93}$ & 0.51 & 0.85 & Mark & $\begin{array}{l}\text { Level of } \\
\text { technical } \\
\text { performance } \\
\text { in javelin } \\
\text { throw }\end{array}$ \\
\hline $76.55 \%$ & $12.83^{*}$ & 1.52 & 18.75 & 1.79 & 10.62 & meter & \begin{tabular}{l}
\multicolumn{3}{l}{ Quantitative } \\
level in \\
javelin \\
throw
\end{tabular} \\
\hline
\end{tabular}

T value is at $0.05=2.160$ significance level

As table (3) shows, there are statistically significant differences at level 0.05 between the pre and the post tests of the first experimental group which uses feedback

form-based motor tasks style in terms of technical and quantitative performance in javelin throw in favor of the post test. 
Table (4)

Indication of the differences between the pre and post tests of the second experimental group in terms of the technical and quantitative performance $\mathrm{N}=14$

\begin{tabular}{|c|c|c|c|c|c|c|c|}
\hline \multirow{2}{*}{$\begin{array}{l}\text { Rate } \quad \text { of } \\
\text { improvement }\end{array}$} & \multirow{2}{*}{$\begin{array}{l}\mathrm{T} \\
\text { value }\end{array}$} & \multicolumn{2}{|l|}{ Post test } & \multicolumn{2}{|l|}{ Pre test } & \multirow{2}{*}{$\begin{array}{lr}\text { Unit } & \text { of } \\
\text { Measurement }\end{array}$} & \multirow[t]{2}{*}{ Variables } \\
\hline & & dependent & Independent & dependent & Independent & & \\
\hline $641.76 \%$ & $20.81 *$ & 0.95 & 6.75 & 0.54 & 0.91 & Mark & $\begin{array}{l}\text { Level of } \\
\text { technical } \\
\text { performance in } \\
\text { javelin throw }\end{array}$ \\
\hline $97.64 \%$ & $14.92 *$ & 1.37 & 20.91 & 1.66 & 10.58 & meter & $\begin{array}{l}\text { Quantitative } \\
\text { level in javelin } \\
\text { throw }\end{array}$ \\
\hline
\end{tabular}

T value is at $0.05=2.160$ significance level

* Statistically significant at level (0.05)

As table (4) shows, there are statistically significant differences at level 0.05 between the pre and the post tests of the second video recorder-based motor tasks style in terms of the technical and quantitative performance in javelin throw in experimental group which uses

Table (4)

Indication of the differences between the pre and post tests of the third experimental group in terms of the technical and quantitative performance $\mathrm{N}=14$

\begin{tabular}{c|c|c|c|c|c|c|c|}
\hline \hline $\begin{array}{l}\text { Rate of } \\
\text { improvement }\end{array}$ & $\begin{array}{l}\mathrm{T} \\
\text { value }\end{array}$ & \multicolumn{2}{|l|}{ Post tests } & \multicolumn{2}{l|}{ Pre tests } & $\begin{array}{l}\text { Unit of } \\
\text { Measurement }\end{array}$ & Variables \\
\hline \hline $762.07 \%$ & $21.97 *$ & 0.92 & 7.50 & 0.55 & 0.87 & Mark & $\begin{array}{l}\text { Level of } \\
\text { technical } \\
\text { performance } \\
\text { in javelin } \\
\text { throw }\end{array}$ \\
\hline $109.50 \%$ & $17.24 *$ & 1.41 & 22.27 & 1.72 & 10.63 & meter & $\begin{array}{l}\text { Quantitative } \\
\text { level in } \\
\text { javelin } \\
\text { throw }\end{array}$ \\
\hline \hline
\end{tabular}

$\mathrm{T}$ value in is at $0.05=2.160$ significance level

* Statistically significant at level (0.05)

As table (4) shows, there group which uses computerare statistically significant differences at level 0.05 between the pre and the post tests of the third experimental based motor tasks style in terms of the technical and quantitative performance in 
javelin throw in favor of the post test.

The researcher attributes the ongoing improvement among the individuals of the three experimental groups in the level of technical and quantitative performance in javelin throw to the efficiency of the multi-forms motor tasks style and the fact that it takes into consideration the individual differences between the learners, which allows the learner to choose her entrylevel in accordance with her own tendencies and potentialities. It's also the learner who assesses her own performance and corrects her own mistakes by means of immediate "feedbacks" as this style provides a set of technical guidelines through the feedback form. The enhancement of video recorder-based and computerbased motor tasks styles has helped in providing live and high-impact experiences which led to increasing the durability of the learning impact and helped the learners to quickly understand and perceive the stages of the technical performance of javelin throw. One of the most important motivation factors for the learner was to try to learn and implement the animation she watches about the skill under consideration.

This result is consistent with the results of the studies of: Schilling \& Mary (2000), Tamer Mahmud El-Said (2006), Ola Abdel-Aal Ibrahim (2010), Najlaa Salama Mohammed (2010) (27), Wael Salama El-Masry (2012), Rania Ibrahim Khamees (2014), Ali Hussein Mubarak (2014) on the efficiency of using multi-forms motor tasks style (feedback form - video recorder - computer) in learning and mastering motor skills while taking into consideration the individual differences between the learners.

This result is also consistent with: Mohsen Hommos (1997), Abu Elnaga Ezz Eddin (2001) who have mentioned that learning by means of the motor tasks style allows each learner to choose the entry-level that corresponds to his abilities, as the teacher provides progressive educational steps of various levels of difficulty so that the learner could choose among them the level that corresponds to his own abilities as a first 
step toward the next task till he achieves the requirements of the last task. This way, the individual differences are taken into consideration, which leads to better results in the educational process and that's what the modern educational trends seek by means of selfeducation which transmits the focus to the learner who is the first beneficiary of the educational process.

Thus, the validity of the first hypothesis has been established.

Table (6)

Indication of the differences between the pre and post tests for the control group in terms of the technical and quantitative performance $\mathrm{N}=14$

\begin{tabular}{|c|c|c|c|c|c|c|c|}
\hline \multirow{2}{*}{$\begin{array}{l}\text { Rate of } \\
\text { improvement }\end{array}$} & \multirow{2}{*}{$\begin{array}{l}\mathrm{T} \\
\text { value }\end{array}$} & \multicolumn{2}{|l|}{ Post test } & \multicolumn{2}{|l|}{ Pre test } & \multirow{2}{*}{$\begin{array}{l}\text { Unit of } \\
\text { measurement }\end{array}$} & \multirow[t]{2}{*}{ Variables } \\
\hline & & dependent & Independent & dependent & Independent & & \\
\hline $461.79 \%$ & $16.34 *$ & 0.66 & 5.00 & 0.53 & 0.89 & Mark & $\begin{array}{l}\text { Level of } \\
\text { technical } \\
\text { performance } \\
\text { in javelin } \\
\text { throw }\end{array}$ \\
\hline $67.51 \%$ & $11.19 *$ & 1.51 & 17.84 & 1.70 & 10.65 & meter & $\begin{array}{l}\text { Quantitative } \\
\text { level in } \\
\text { javelin } \\
\text { throw }\end{array}$ \\
\hline
\end{tabular}

T value is at $0.05=2.160$ significance level

As table (6) shows, there are statistically significant differences at level 0.05 between the pre and the post tests of the control group in terms of the level of technical and quantitative performance in javelin throw in favor of the post test.
Second: presentation and discussion of the results of the second hypothesis which stipulates that: "there are statistically significant differences between the averages of the pre and post tests of the control group (command teaching style) in terms of the level of technical and quantitative performance in the javelin throwing skill in favor of the post test."
The researcher attributes the improvement among the individuals of the control group in the level of technical and quantitative performance in javelin throw to the efficiency of the command teaching style (the traditional style) where the teacher gives simplified verbal

\footnotetext{
Assiut Journal For Sport Science Arts
} 
explanations, performs the practical model and provides feedbacks on the skill under consideration.

Thus, the validity of the second research hypothesis has been established.

Third: presentation and discussion of the results of the third hypothesis which stipulates that: "there are

Table (7)

Indication of the differences between the post tests of the four groups of the research in terms of the level of technical and quantitative performance of javelin throwing

\begin{tabular}{c|c|c|c|l|l|l|}
\hline \hline F value & $\begin{array}{l}\text { Total sum } \\
\text { of squares }\end{array}$ & $\begin{array}{l}\text { Degree of } \\
\text { freedom }\end{array}$ & $\begin{array}{l}\text { Mean } \\
\text { square }\end{array}$ & $\begin{array}{l}\text { Source } \\
\text { variance }\end{array}$ & Variables \\
\hline \hline \multirow{3}{*}{$3.92^{*}$} & 4.31 & 3 & 12.94 & $\begin{array}{l}\text { Between the } \\
\text { groups }\end{array}$ & $\begin{array}{l}\text { Level of technical } \\
\text { performance in javelin } \\
\text { throwing }\end{array}$ \\
\cline { 2 - 6 } & 1.10 & 52 & 57.28 & Among groups & $\begin{array}{l}\text { Level of quantitative } \\
\text { performance in javelin } \\
\text { throwing }\end{array}$ \\
\hline \multirow{3}{*}{$4.11^{*}$} & 5.71 & 3 & 17.12 & $\begin{array}{l}\text { Between } \\
\text { groups }\end{array}$ \\
\cline { 2 - 5 }
\end{tabular}

$\mathrm{T}$ value at $0.05=2.160$ significance level

*Statistically significant at 0.05

As table (7) shows, there are statistically significant differences at level 0.05 between the post tests of the three experimental groups and the control group in terms of technical and quantitative performance in javelin throw,

which means that there is a difference between the marks of all the four groups. Accordingly, the significant differences between the averages have been calculated by LSD test.

Table (8)

Indication of the differences between the average post tests of the four groups of the research in terms of the level of technical and quantitative performance of javelin throwing Assiut Journal For Sport Science Arts 


\begin{tabular}{|c|c|c|c|c|}
\hline \multicolumn{2}{|c|}{$\begin{array}{l}\text { least significant } \\
\text { difference (LSD) }\end{array}$} & \multirow[t]{2}{*}{ Arithmetic mean } & \multirow[t]{2}{*}{$\begin{array}{l}\text { Research } \\
\text { groups }\end{array}$} & \multirow[t]{2}{*}{ Variables } \\
\hline Second & First & & & \\
\hline \multirow[t]{4}{*}{$0.82 *$} & & 5.93 & $\begin{array}{l}\text { First } \\
\text { experimental }\end{array}$ & \multirow{4}{*}{$\begin{array}{l}\text { Level of } \\
\text { technical } \\
\text { performance } \\
\text { in javelin } \\
\text { throw }\end{array}$} \\
\hline & & 6.75 & $\begin{array}{l}\text { Second } \\
\text { experimental }\end{array}$ & \\
\hline & & 7.50 & $\begin{array}{l}\text { Third } \\
\text { experimental }\end{array}$ & \\
\hline & & 5.00 & $\begin{array}{l}\text { Control } \\
\text { group }\end{array}$ & \\
\hline \multirow[t]{4}{*}{$2.16^{*}$} & & 18.75 & $\begin{array}{l}\text { First } \\
\text { experimental }\end{array}$ & \multirow{4}{*}{$\begin{array}{l}\text { Level of } \\
\text { quantitative } \\
\text { performance } \\
\text { in javelin } \\
\text { throw }\end{array}$} \\
\hline & & 20.91 & $\begin{array}{l}\text { Second } \\
\text { experimental }\end{array}$ & \\
\hline & & 22.27 & $\begin{array}{l}\text { Third } \\
\text { experimental }\end{array}$ & \\
\hline & & 17.84 & $\begin{array}{l}\text { Control } \\
\text { group }\end{array}$ & \\
\hline
\end{tabular}

As table (8) shows, there are statistically significant differences between the post tests of the four groups in terms of the technical and quantitative performance in javelin throw in favor of the third experimental group (computer-based motor tasks style) while the second experimental group that has adopted the video recorderbased motor tasks style has surpassed the first experimental group which has adopted feedback form-based motor tasks style and the control group in terms of the variables under consideration. The first experimental group which had used feedback formbased motor tasks style has also surpassed the control group which had adopted the command teaching style in terms of the variables under consideration.

The researcher attributes the superiority of the third experimental group in terms of the level of technical and quantitative performance in javelin throwing skills over the other experimental groups and

\section{Assiut Journal For Sport Science Arts}


the control group to the fact that the third experimental group had adopted the computer-based motor tasks style in learning the relevant skill, given that using computer in the educational process has helped in creating an active and efficient educational environment where the learner can participate actively and has the desire, the motivation and the challenge to learn and to master the javelin throwing skill however difficult was it, as well as the computer's ability to display written texts besides illustrations in an attractive and interesting manner that draws the learner's attention.

These results are consistent with the results of the following studies: Angrola Scott (2005), Tamer Mahmud El-Saeed (2006), Abdurrahman Abdulfattah Mohammed (2005), Khalid Khamees Jabir (2009), Chung Tae Won (2009), Wael Salama El-Masry (2012), Wael Salama El-Masry and Hisham Ali El-Aqra' (2013, and Rania Ibrahim Khamees (2014) on the efficiency of multimedia software (video recorder computers) in learning and mastering motor skills in individual and team sports compared to the traditional method.

These results are also consistent with: Gigging, et., al (1997), Donal (2002) who have indicated that that the means of technological education play a crucial role in the development of the educational process and the quality of learning outcomes. Some studies have pointed out that the learning outcomes for the learners who have been taught by computer surpasses traditional education, which means that the use of computers in education saves $33 \%$ of time. The studies have also indicated that the trends of the teachers have become positive.

Furthermore, the researcher attributes the positive progress of the second experimental group compared to the first experimental group (feedback form) and the control group to the fact that the second experimental group had used video recordersupported motor tasks style, given that the use of video recorder has helped the learners to understand well and visualize correctly the performance of the skills as well as to understand the stages 
of the technical performance of javelin throw. With the video recorder, the display can be stopped or replayed many times, with slow/fast motion features. Skills can also be reenacted through live and realistic models of performance.

This result is consistent with: Mohammed Saad Zaghloul et.,al (2001) who have pointed out that the use of video recorder in the educational process has many pedagogical advantages that include creating suspense and interest, flexibility of the recorded animations (skipping and playbacks - slow/fast motions), saving learning time and effort and helping in learning difficult motor skills that can't be easily explained in a theoretic manner. So, it is one of the mean that are the most similar to reality.

Thus, the validity of the third hypothesis has been established.

\section{Findings:}

1- The efficiency of using multi-forms motor tasks style (feedback form - video recorder - computer) in learning javelin throwing skills for the second-year students at the Faculty of Physical Education for Girls at Zagazig. 2- The efficiency of using command teaching style (verbal explanations - practical model - correcting technical mistakes) in learning and mastering javelin throwing skills for the second-year students at the Faculty of Physical Education for Girls at Zagazig.

3- Using computersupported motor tasks style has achieved the best results in learning and mastering javelin throwing skills for the secondyear students at the Faculty of Physical Education for Girls at Zagazig.

4- Using video recordersupported motor tasks style has achieved better and more efficient results in learning and mastering javelin throwing skill than the use of feedback form-based motor tasks style and the control group.

5- The use of feedback form-based motor tasks style has achieved better and more efficient results in learning and mastering javelin throwing skills than the use of command teaching style (the control group).

Recommendations:

1- Using computer-based 
motor tasks method given its effective impact on the learning and mastery of javelin throwing skills for the secondyear students at the Faculty of Physical Education for Girls at Zagazig University.

2- Incorporating modern and advanced educational means-based teaching styles (video recorder - computer) in the program of track and field events for the second-year students at the Faculty of Physical Education for Girls at Zagazig University.

3- The importance of the use of non-typical teaching styles in teaching the practical aspect of the program of track and field at the Faculties of Physical Education.

4- Conducting similar studies in order to prove the efficiency of multi-forms motor tasks style (feedback form - video recorder computer) by using other samples and skills within the program of track and field events at the Faculties of Physical Education.

Bibliography:

First: Arabic references:

1- Abu El-Naga Ezz Eddin (2001): Physical Education Teacher, Dar ElAsdeka', El-Mansoura.
2- Abu El-Naga Ezz

Eddin (2005): Teaching in Physical Education (Methods Styles - Strategies), Shajarat El-Dor library, El-Mansoura.

3- El-Sayed Mohamed Khairy (1989): Intelligence Test (Instructions and Applications), Dar El-Nahda El-Arabia - Cairo

4- IAAF - International Association of Athletics Federations (2012) the International Law of Athletics, Cairo.

5- Bastaweesy Ahmed Bastaweesy (1997): Track and Field Events, Education Tactics - Training, Dar El-Fikr Al-Araby, Cairo.

6- Tamer Mahmud ElSaeed (2006): the Effects of the Use of Multi-Forms Motor Tasks Style on the Learning of some Attack Skills in Handball for the Students of the Faculty of Physical Education (comparative study), Master thesis, Faculty of Physical Education, Mansoura University.

7- Khalid Khamees Jabir (2009): the Effect of Using Computer and Internet in Learning the Skill of (Discus Throw) among the Students of the Faculty of Basic Education / University of Diyala, Sportive 
Sciences Magazine, $1^{\text {st }}$ release, Faculty of Physical Education, University of Diyala, Iraq. 8- Rania Ibrahim Khamees (2014): the Effect of Using Multi-Forms Motor Tasks Style on the Learning of some Basic Skills in Hockey", $\mathrm{PhD}$ thesis, Faculty of Physical Sciences for Girls, University of Alexandria.

9- Zaki Darweesh, Adel Abdul-Hafez

(1994):

Encyclopedia of Athletics, Throw Events and Combined Events, Dar El-Maaref, Cairo. 10- Saeed Khalil ElShahed (1997): Methods of Teaching in Physical Education, the University Library, Cairo.

\section{1- Abdelhalim}

\section{Mohammed Abdelhalim,} (2002) et.,al, Track and Field Events, Theories and Applications, Dar El-Wafaa for Printing and Publishing, Alexandria.

\section{2- Abdurrahman}

Abdulhamid Zaher (2001): Encyclopedia of the Physiology of Throw Events (1000 Trainings for Physiological, Motor and Skill Competences), Dar El-Kitab for Publishing, Cairo.

13- Abdurrahman

\section{Abdulfattah Mohammed}

(2008): "the Effect of Using Digital multimedia and Hypermedia on the Learning of Triple Jumping for the Students of the Preparatory Cycle (Comparative study), master thesis, Faculty of Physical Education, Mansoura University.

14- Afaf Abdulkarim Hassan (1994): Teaching for Acquisition in Physical Education, Styles and Strategies, Assessment, Monsha'at El-Ma'ref, Alexandria.

\section{5- Afaf Abdulkarim}

Hassan (1995): Motor

Programs for Teaching Children, Monsha'at El-Ma'ref, Alexandria.

\section{6- Ola Abdula'l Ibrahim} (2010): the Efficiency of the Methods of Multi-levels SelfApplication Style and Directed Discovery on the Learning of some Gymnastics Skills for the Students of the First Cycle of Primary Education", Master thesis, Faculty of Physical Education, Tanta University.

17- Ali Hassan Mubarak (2014): "the Efficiency of Using Multi-levels SelfApplication Style on the Learning of Dolphin Swimming for the Students at Kuwait", Physical Education 
Researches Magazine, Vol. (48), release (94), $1^{\text {st }}$ part, Faculty of Physical Education for Boys, Zagazig University. 18- Fayez Mourad, ElAmine Abdul-Hafez (2003): Guide of Practical Education and Teacher Preparation, Dar El-Wafaa for Publishing and Printing, Alexandria.

\section{9- Farrag Abdulhamid}

Tewfik (2004) Encyclopedia of Athletics - Technical Aspects of Push and Throw Events, Dar El-Wafaa for Publishing and Printing, Alexandria.

20- Fekry Hassan Rayan (2004): Teaching "Objectives Basics - Results Assessment Applications" Alam El-Kotob, Cairo.

21- Kamal Jameel ElRabdy (1998): Latest Athletics News, Dar El-Maktaba ElWataniya, Cairo.

\section{2- Mohsen Mohammed} Hems (1997): The Guide in Physical Education Teaching, Monsha'at El-Maaref, Alexandria.

23- Mohammed Hassan Allawy, Mohammed Nasr Eddin Radwan (2001): Motor Performance Tests, $4^{\text {th }}$ ed., Dar El-Fikr El-Araby, Cairo.

\section{4- Mohammed Sa'd} Zaghloul, Makarem Helmy
Abu Harga, Hany Abdumoneim

(2001):

Educational Technology and its Styles in Physical Education, Markaz El-Kotob for Publishing, Cairo.

25- Mahmud Abdulhalim Abdulkarim (2006): The Dynamics of Physical Education Teaching, Markaz El-Kotob for Publishing, Cairo. 26- Najlaa Salama Mohammed (2010): "the Effect of Using Motor Tasks Styles and Collaborative Working on the level of Skill Performance on the Balance Beam Apparatus", Sportive Sciences and Arts Magazine, Vol. (37), Faculty of Physical Education for Girls, Helwan University.

27- Wael Salama El-Masry (2012): "the Efficiency of Containment Style on Learning the Skills of Shut Pot and Triple Jump for the Students of the $10^{\text {th }}$ Cycle", Humanities Series, Vol. (14), $1^{\text {st }}$ release, Al-Azhar University Magazine, Gaza, Palestine.

28- Wael Salama ElMasry, Hisham Ali El-Aqra' (2013): "the Effects of Interactive Video on Skill Performance and Quantitative Level of Shot Put for the Students of the Faculty of 
Physical Education at the AlAqsa", Magazine of the Islamic University for Educational and Psychological Studies, $21^{\text {st }}$ Vol., $1^{\text {st }}$ release.

Second: Foreign References:

30- Alfred, B., (2003): Problems the Commands Stylesin Physical Education, Journal Educational Research, Vol. 14, No., 40.

31- Angorla Scott (2005): The Effects of Multimedia Tutorials and Observational Learning on Cognitive Outcomes and Skill Acquisition in Basketball, New York University.

32- Chung -Tae won (2009): The Effectiveness of computer Based Interactive video Instruction on psychomotor skill Analysis Competency of preservice physical education Teachers in tennis Teaching, University of Northen Colorrodo Dissertation Abstracts
International.

33- Donal, S., (2002):

Teaching by Multimedia as Systems Approach Spot Media, New York.

34- Gigging, N.,et.,al (1997): Instructional Technology in Higher Education Teaching, Quest (champing, Lii) 49 (3), Aug, 1997,280-290 Reps: 24.

35- Joce Harrison (1996): Instructional Strategies for Secondary School Physical Educationm 4 ed., Brawn Bench Mark.

36- Schilling \& Mary (2000): The Effect of Three Styles of Teaching on University Students Sports Performance., htt: // ericirsyedu / Pluels. Cgi.

37- Singer, R., \& Dick, W., (1998): Teaching physical Education, a system approach. 2ed, Boston. 